\title{
CLINICAL PROFILE AND OUTCOME OF PATIENTS WITH HYPONATREMIA AT TERTIARY CARE TEACHING HOSPITAL
}

Virendra C. Patil1 ${ }^{1}$,Harsha V. Patil2, Ipsita B. Malakar ${ }^{3}$

1 Professor and HOD, Department of Medicine, Krishna Institute of Medical Sciences Deemed to be University, Karad, Maharashtra, India.

${ }^{2}$ Associate Professor, Department of Microbiology, Krishna Institute of Medical Sciences Deemed to be University, Karad, Maharashtra, India.

${ }^{33^{\text {rd }}}$ Year Junior Resident, Department of Medicine, Krishna Institute of Medical Sciences Deemed to be University, Karad, Maharashtra, India.

\section{BACKGROUND}

\section{ABSTRACT} \\ Hyponatremia is defined as a serum sodium concentration less than $135 \mathrm{mmol} / \mathrm{L}$ and is the most common electrolyte disorder \\ encountered in clinical practice.
}

\section{MATERIALS AND METHODS}

This was a retrospective, descriptive and data analysis study conducted over period of 12 month at a tertiary care centre, to study the clinical profile, aetiology, classification and outcome of hyponatremia. A total 115 consecutive cases who had serum sodium levels of $<135 \mathrm{mmol} / \mathrm{L}$ were enrolled. The mean and standard deviation and percentage for numerical variables were calculated. Chi square test was used to analyse categorical variables.

\section{RESULTS}

Of a total of 115 patients, $73(63.47 \%)$ were male and $42(36.52 \%)$ were females. There was a predominance of $\mathrm{Na}^{+}$levels of $115-$ $134 \mathrm{mmol} / \mathrm{L}$ (mild hyponatremia) 59.13\% [' $\left.\mathrm{p}^{\prime}<0.001\right]$. The majority of patients $(42.61 \%$ ) had nausea and/or vomiting ('p'<0.001) and confusion, seizures and coma were associated with moderate to profound hyponatremia ('p' <0.01). The SIADH (37.39\%) was the commonest pathophysiological process observed in the present study [' $p$ ' $<0.0001]$. Overall mortality was $9.57 \%$. The patients with Sr. $\mathrm{Na}^{+}<105 \mathrm{mmol} / \mathrm{L}$ had (36.84\%) significant mortality compared to $>105 \mathrm{mmol} / \mathrm{L}$ ['p' $\left.<0.002196\right]$. The duration of hospital stay was inversely related to Sr. sodium level.

\section{CONCLUSION}

In present cohort of hyponatremia the SIADH was the commonest aetiology. Confusion, seizures and coma were associated with moderate to profound hyponatremia. The duration of hospital stay was inversely related to serum sodium level with overall mortality of $9.57 \%$ which was correlated with severity of hyponatremia.

\section{KEY WORDS}

Hyponatremia, SIADH, Serum Sodium Level, Seizures, Coma.

HOW TO CITE THIS ARTICLE: Patil VC, Patil HV, Malakar IB. Clinical profile and outcome of patients with hyponatremia at tertiary care teaching hospital. J. Evolution Med. Dent. Sci. 2018;7(53):5591-5596, DOI: 10.14260/jemds/2018/1237

\section{BACKGROUND}

Hyponatremia is defined as a serum sodium concentration less than $135 \mathrm{mmol} / \mathrm{L}$ and is the most common electrolyte abnormality encountered in clinical practice including intensive care unit. Mild hyponatremia has been estimated to occur in about $30 \%$, whereas the prevalence of moderate to severe hyponatremia is about $7 \%$ among hospitalized patients. Hyponatremia especially severe associated significant morbidity and mortality. Acute severe hyponatremia is a medical emergency accompanied by severe neurological symptoms due to cerebral oedema and can be life-threatening if not recognized and appropriately treated.

'Financial or Other Competing Interest': None.

Submission 23-11-2018, Peer Review 17-12-2018,

Acceptance 24-12-2018, Published 31-12-2018.

Corresponding Author:

Harsha V. Patil,

Associate Professor,

Department of Microbiology,

KIMS Deemed to be University, Karad,

Satara-415110, Maharashtra, India.

E-mail: virendracpkimsu@rediffmail.com

DOI: $10.14260 /$ jemds/2018/1237
The rapid correction of chronic hyponatremia may results in osmotic demyelination syndrome (Central pontine myelinosis).[1,2,3] The present study was conducted to evaluate clinical, etiological profile and outcome of patents presenting with hyponatremia at tertiary care centre.

\section{MATERIALS AND METHODS}

Aims and Objectives

To study clinical profile, aetiology, classification and outcome of Hyponatremia at a tertiary care center.

\section{Study Design and Setting}

This was a retrospective, descriptive; data analysis study of patients admitted over period of 12 month with diagnosis of hyponatremia, at a tertiary care center. The study was conducted at Krishna Institute of Medical Sciences and Deemed to be University, Karad, Maharashtra. The study was approved by the institutional ethics and protocol committee.

\section{Inclusion Criteria}

The patients of age 18 years or more and who were hyponatremia on admission were included in the study. 


\section{Exclusion Criteria}

Patients who developed hyponatremia during hospital stay were excluded.

Detailed history including onset, duration, progression of symptoms, history of illnesses and detailed general and physical examinations of the patients were done.

\section{Laboratory Investigation}

The measurements of sodium $\left(\mathrm{Na}^{+}\right)$, potassium $\left(\mathrm{K}^{+}\right)$, urea, creatinine and glucose concentration were done by standard laboratory methods. Serum osmolality was measured using the formula $[2 \mathrm{x}(\mathrm{Na}+\mathrm{K})]+(\mathrm{BUN} / 2.8)+($ glucose $/ 18)] \cdot{ }^{[4]}$ The urinary $\mathrm{Na}^{+}$was calculated as per standard protocol. The relevant other investigations were done as per need for the study.

A total 115 consecutive cases who had serum Sodium levels of $<135 \mathrm{mmol} / \mathrm{L}$ were enrolled and studied admitted during a period of 12 months from July 2017 to June 2018 After establishing the diagnosis of hyponatremia, the patients were categorized based on the level of hyponatremia into mild, moderate and severe hyponatremia.[1]

1. A 'Mild' hyponatremia: If serum sodium concentration between 130 and $134 \mathrm{mmol} / \mathrm{l}$.

2. A 'moderate' hyponatremia: If serum sodium concentration between 125 and $129 \mathrm{mmol} / \mathrm{l}$.

3. 'Profound' hyponatremia: serum sodium concentration $<125 \mathrm{mmol} / \mathrm{l}$

4. Acute hyponatremia, that is documented to exist $<48 \mathrm{~h}$. and chronic hyponatremia as hyponatremia that is documented to exist for at least $48 \mathrm{~h}$.

The patients with hyponatremia were then further evaluated to find out the aetiology. Serum and urine osmolality was calculated [Normal osmolality: 275-295 mosm $/ \mathrm{kg} \mathrm{H}_{2} \mathrm{O}$ ]. They were then assessed clinically to find out the volume status clinically if they had low serum osmolality-

1. Hypervolemia: Presence of bilateral basal crepitation, raised jugular venous pressure, bilateral pitting pedal oedema and hepatomegaly.

2. Hypovolemia: Presence of tachycardia, postural hypotension, dry tongue, nature of skin turgor and urine output.

3. Euvolemic: Those patients who had no signs mentioned above were considered to be euvolemic.

\section{Statistical Analysis}

The mean and standard deviation and percentage for numerical variables were calculated. Chi-square test was used to analyze categorical variables. ANOVA was used to compare mean of duration of stay in patients with hyponatremia.

\section{RESULTS}

A total 115 patients fulfilling inclusion criteria of study with diagnosis of hyponatremia were enrolled, the mean and SD for age was $51.63 \pm 13.73$ years and sodium was 113.57 meq/L. A total 73 (63.47\%) were male and 42 (36.52\%) were females in present study. (Table 1) Of total 115 patients with hyponatremia, $18.26 \%$ had serum $\mathrm{Na}^{+}$levels $<105 \mathrm{mmol} / \mathrm{L}$. (Severe hyponatremia), $22.60 \%$ had 105 - $115 \mathrm{mmol} / \mathrm{L}$ (Moderate Hyponatremia) and 59.13\% had 115-134 mmol/L (Mild hyponatremia) with predominance of $\mathrm{Na}^{+}$level 115-134 $\mathrm{mmol} / \mathrm{L}$ (Mild hyponatremia) ['p'<0.001, DF:2]. (Table 2)

\begin{tabular}{|c|c|c|}
\hline Variables & Mean & SD ( \pm ) \\
\hline Age & 51.63 & 13.73 \\
\hline Duration of Stay & 13.5 & 6.3 \\
\hline $\mathrm{Na}^{+}$ & 113.57 & 12.97 \\
\hline $\mathrm{K}^{+}$ & 4.05 & 0.86 \\
\hline $\mathrm{BSL}$ & 170.11 & 45.20 \\
\hline Serum Creatinine & 1.45 & 0.50 \\
\hline Males: 73 (63.47\%), Females: 42 (36.52\%) \\
\hline Table 1. Mean and Standard Deviation of Patients with \\
Hyponatremia \\
\hline
\end{tabular}

\begin{tabular}{|c|c|c|}
\hline $\begin{array}{c}\text { Severity of Hyponatremia according } \\
\text { to Serum Sodium Levels }\end{array}$ & $(n=115)$ & $\%$ \\
\hline $\begin{array}{l}\text { Severe Hyponatremia } \\
\left(\mathrm{Sr} . \mathrm{Na}^{+}<105 \mathrm{mmol} / \mathrm{L} .\right)\end{array}$ & 21 & 18.26 \\
\hline $\begin{array}{l}\text { Moderate Hyponatremia } \\
\left(\mathrm{Sr} . \mathrm{Na}^{+} 105-115 \mathrm{mmol} / \mathrm{L}\right)\end{array}$ & 26 & 22.60 \\
\hline $\begin{array}{c}\text { Mild Hyponatremia } \\
(\mathrm{Sr} . \mathrm{Na}+115-134 \mathrm{mmol} / \mathrm{L})\end{array}$ & 68 & 59.13 \\
\hline Total & 115 & 100 \\
\hline
\end{tabular}

Table 2. Total Number of Patients according to the Severity of Sr. Sodium

The majority of patients (42.61\%) had nausea and or vomiting as presenting feature of hyponatremia ('p'<0.001) with predominant mild to moderate' hyponatremia. The confusion, seizures and coma are the less common in present study and usually associated with moderate to profound hyponatremia ('p'<0.01). The mild hyponatremia $(59.13 \%)$ was common in present study followed by moderate $(22.60 \%)$ and profound (18.26\%) [' $p$ ' $=0.0012]$. There was no significant statistical difference between severity of hyponatremia and volume status of the patients [' $p$ ' $=0.7168]$. (Table 3)

\begin{tabular}{|c|c|c|c|c|c|c|c|c|}
\hline \multicolumn{4}{|c|}{ Symptomatology } & \multicolumn{3}{|c|}{$(n=115)$} & \multicolumn{2}{|c|}{$\%$} \\
\hline \multicolumn{4}{|c|}{ Nausea and or Vomiting } & \multicolumn{3}{|c|}{49} & \multicolumn{2}{|c|}{42.61} \\
\hline \multicolumn{4}{|c|}{ Lethargy } & \multicolumn{3}{|c|}{31} & \multicolumn{2}{|c|}{26.96} \\
\hline \multicolumn{4}{|c|}{ Confusion } & \multicolumn{3}{|c|}{17} & \multicolumn{2}{|c|}{14.78} \\
\hline \multicolumn{4}{|c|}{ Bizarre Behaviour } & \multicolumn{3}{|c|}{7} & \multicolumn{2}{|c|}{6.09} \\
\hline \multicolumn{4}{|c|}{ Seizures } & \multicolumn{3}{|c|}{7} & \multicolumn{2}{|c|}{6.09} \\
\hline \multicolumn{4}{|c|}{ Coma } & \multicolumn{3}{|c|}{4} & \multicolumn{2}{|c|}{3.48} \\
\hline \multicolumn{4}{|c|}{ Total } & \multicolumn{3}{|c|}{115} & \multicolumn{2}{|c|}{100} \\
\hline \multicolumn{9}{|c|}{$\mathrm{X}^{2} ; \mathrm{DF}: 5 ;{ }^{\prime} \mathrm{p}^{\prime}<0.001$} \\
\hline 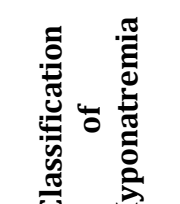 & \multicolumn{2}{|c|}{$\bar{\Sigma}$} & \multicolumn{2}{|c|}{ 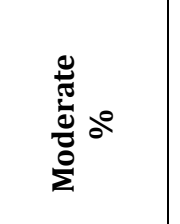 } & \multicolumn{2}{|c|}{ 总 } & \multicolumn{2}{|c|}{$\overbrace{0}^{\pi} 0$} \\
\hline Euvolemia & 21 & 51.22 & 11 & 26.83 & 9 & 11.00 & 41 & 35.65 \\
\hline Hypervolemia & 24 & 60.00 & 9 & 22.50 & 7 & 9.00 & 40 & 34.78 \\
\hline Hypovolemia & 23 & 67.65 & 6 & 17.65 & 5 & 6.00 & 34 & 29.57 \\
\hline Total & 68 & 59.13 & 26 & 22.60 & 21 & 18.26 & 115 & 100 \\
\hline \multicolumn{9}{|c|}{$\mathrm{X}^{2}: 2.1033 ;$ DF: $4 ;$; $\mathrm{p}^{\prime}: 0.7168$} \\
\hline $\begin{array}{r}\text { Table 3. Sy } \\
\text { Volun }\end{array}$ & $\mathrm{seO}$ & $\begin{array}{l}\text { matolo } \\
\text { tus of } F\end{array}$ & $g y, S$ & everity & & & & d \\
\hline
\end{tabular}

The SIADH (37.39\%) was the commonest aetiology observed in present study ['p' $<0.0001]$. The diuretics (18.26\%), cardiac (13.04\%), gastrointestinal loss $(7.83 \%)$ and chronic kidney disease (CKD) $(7.83 \%)$ were the other disease condition associated with hyponatremia in present study. Of total 115 patients presented with hyponatremia 11 
patients died with overall mortality of $(9.57 \%)$. The patients with Sr. $\mathrm{Na}^{+}<105 \mathrm{mmol} / \mathrm{L}$ had (36.84\%) significant mortality compared to $>105 \mathrm{mmol} / \mathrm{L}$ [' $\mathrm{p}$ ' <0.002196]. (Table 4 and Graph 1) The duration of hospital stay was inversely related to $\mathrm{Sr}$. $\mathrm{Na}^{+}$level in present study with negative correlation $[\mathrm{Sr}$. $\mathrm{Na}^{+}<105 \mathrm{mmol} / \mathrm{L} 19.3( \pm 9.5), 105-115 \mathrm{mmol} / \mathrm{L} 9.2$ ( \pm 5.9$)$, 115-134 mmol/L 5.7 ( \pm 2.4$)]$. (Table 4)

\begin{tabular}{|c|c|c|}
\hline Aetiology & (n=115) & \% \\
\hline SIADH & 43 & 37.39 \\
\hline Drugs (Diuretics) & 21 & 18.26 \\
\hline Renal Salt Wasting & 7 & 6.09 \\
\hline Gastrointestinal Loss & 9 & 7.83 \\
\hline Endocrine Disorders & 5 & 4.35 \\
\hline Cardiac & 15 & 13.04 \\
\hline Cirrhosis of Liver & 6 & 5.22 \\
\hline CKD & 9 & 7.83 \\
\hline Total & 115 & 100 \\
\hline
\end{tabular}

\begin{tabular}{|c|c|c|}
\hline \multicolumn{3}{|c|}{$\mathrm{X}^{2}$ : 66.48; DF: 7; ' $\mathrm{p}^{\prime}:<0.0001$} \\
\hline $\begin{array}{l}\text { Serum Sodium } \\
\text { Level }\end{array}$ & $\begin{array}{c}\text { Mean Duration } \\
\text { of Stay }\end{array}$ & SD ( \pm ) \\
\hline $\begin{array}{c}\text { Serum Sodium }<105 \\
\text { mmol/L. }(n=21)\end{array}$ & 19.3 & 9.5 \\
\hline $\begin{array}{c}\text { Serum Sodium } 105-115 \\
\mathrm{mmol} / \mathrm{L}(\mathrm{n}=26)\end{array}$ & 9.2 & 5.9 \\
\hline $\begin{array}{c}\text { Serum Sodium 115-134 } \\
\mathrm{mmol} / \mathrm{L}(\mathrm{n}=68)\end{array}$ & 5.7 & 2.4 \\
\hline Mortality & $(n=11)$ & $\%$ \\
\hline Sr. $\mathrm{Na}^{+}<105 \mathrm{mmol} / \mathrm{L}$. & 7 & 33.33 \\
\hline Sr.Na+ $105-115 \mathrm{mmol} / \mathrm{L}$ & 3 & 11.53 \\
\hline Sr.Na+115-134 mmol/L & 1 & 1.4 \\
\hline Total & 11 & 9.57 \\
\hline \multicolumn{3}{|c|}{$\mathrm{X}^{2}: 7.63 ;$ DF: $2 ;$ 'p': <0.00219 } \\
\hline with Durat & 2 & $\begin{array}{l}\text { Levels } \\
y\end{array}$ \\
\hline
\end{tabular}

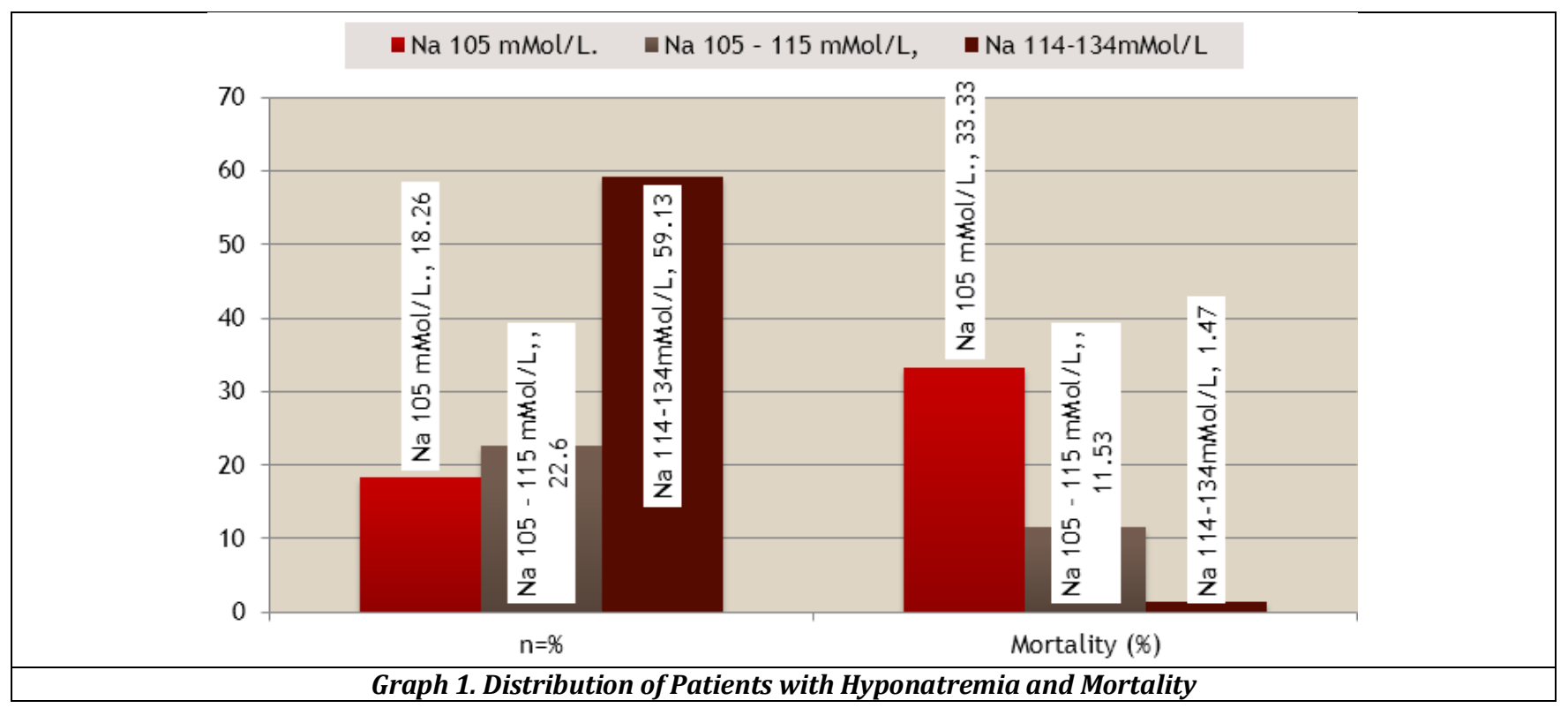

Of total 115 patients presented with hyponatremia, CVA (9.57\%), diabetes mellitus, hypertension (7.83\%) and diabetes mellitus $(7.83 \%)$ were the relatively frequent diagnosis in present study. (Table 5)

\begin{tabular}{|c|c|c|c|c|c|c|c|c|}
\hline 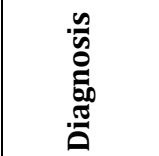 & $=$ & $\overbrace{}^{0}$ & 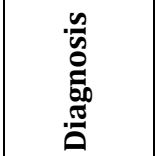 & $=$ & $\delta^{0}$ & 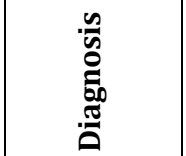 & $=$ & $0^{0}$ \\
\hline CKD & 9 & 7.83 & Malignancy & 3 & 2.61 & DM and HTN & 9 & 7.83 \\
\hline AKI & 7 & 6.09 & UTI & 5 & 4.35 & COPD & 4 & 3.48 \\
\hline Collagen VD & 8 & 6.96 & AMI & 7 & 6.09 & Anaemia & 2 & 1.74 \\
\hline CCF & 8 & 6.96 & PTE & 1 & 0.87 & Cirrhosis & 6 & 5.22 \\
\hline Pneumonia & 8 & 6.96 & Seizure & 3 & 2.61 & BEP & 2 & 1.74 \\
\hline CVA & 11 & 9.57 & Jaundice & 1 & 0.87 & Psychiatric D. & 1 & 0.87 \\
\hline AGE & 3 & 2.61 & $\begin{array}{c}\text { Atrial } \\
\text { fibrillation }\end{array}$ & 3 & 2.61 & $\begin{array}{c}\text { Pulmonary } \\
\text { HTN }\end{array}$ & 1 & 0.87 \\
\hline $\begin{array}{l}\text { Hyper- } \\
\text { tension }\end{array}$ & 1 & 0.87 & RVD & 1 & 0.87 & RA & 1 & 0.87 \\
\hline DM & 9 & 7.83 & PTB & 1 & 0.87 & & & \\
\hline
\end{tabular}

\section{Abbreviations}

CKD: Chronic kidney disease, AKI: Acute Kidney Injury, PTE: pulmonary thrombo-embolism, RVD: retroviral Disease, PTB: pulmonary tuberculosis, AMI: acute myocardial infarction, BEP: benign enlargement of prostate, RA: rheumatoid arthritis)

Of total 115 patients with hyponatremia Renal disease was present in $18.26 \%$, CNS in $13.04 \%$, infections in $16.52 \%$, HTN and DM in $15.65 \%$ and cardiovascular diseases were present in $15.65 \%$. (Table 6)

\begin{tabular}{|c|c|c|}
\hline Systems Affected & (n=115) & \% \\
\hline Renal Disease & 21 & 18.26 \\
\hline Liver Disease & 7 & 6.09 \\
\hline Infection & 19 & 16.52 \\
\hline CNS & 15 & 13.04 \\
\hline HTN and DM & 18 & 15.65 \\
\hline Pulmonary & 6 & 5.22 \\
\hline Haematological & 2 & 1.74 \\
\hline Collagen Vascular & 9 & 7.83 \\
\hline Cardiovascular & 18 & 15.65 \\
\hline Total & $\mathbf{1 1 5}$ & $\mathbf{1 0 0}$ \\
\hline Table 6. Systems Association with Hyponatremia \\
\hline \multicolumn{3}{|c}{}
\end{tabular}




\section{DISCUSSION}

Hyponatremia occurs in up to $8 \%$ of the general population and in up to $60 \%$ of hospitalized patients. Acute profound hyponatremia can cause brain oedema, but also chronic mild hyponatremia is associated with poor health outcomes. Even when co-morbid conditions are taken into account, people with a mildly decreased serum sodium concentration have a $30 \%$ higher risk of death and are hospitalized $14 \%$ longer relative to those without hyponatremia. ${ }^{[5]}$ Hyponatremia is often iatrogenic in in patients and severe sodium disturbances are associated with considerable morbidity and mortality.The management of Hyponatremia is always associated with diversity of aetiology and volume status of the patients and different disease conditions. The hyponatremia is managed by clinicians with a broad variety of backgrounds have diverse institution specialty based approaches to manage the same.[6]

In current study on cohort of hyponatremia, $63.47 \%$ were males and $36.52 \%$ were females with mean age of $51.63 \pm 13.73$ years with predominance of male population. The majority of patients (42.61\%) had nausea and or vomiting $($ ' $\mathrm{p}$ '<0.001). The confusion, seizures and coma are the less common in present study and associated with moderate to profound hyponatremia (' $\mathrm{p}$ ' $<0.01$ ). The SIADH (37.39\%) was the commonest pathophysiological process observed ['p' <0.0001] for hyponatremia. Similarly, Nandakumar et al reported drowsiness was commonest symptom (53.2\%) followed by vomiting, hiccoughs and seizures. About half of the patients had euvolemic hyponatremia 39\% had hypovolemic hyponatremia and SIADH was the commonest cause of hyponatremia. Hyponatremia was common in elderly. Seizures were present only in severe hyponatremia.[7] Mittal M et al studied 250 patients with mean age of 53.9 years predominated by males with $61.6 \%$ patients had euvolemic $21.2 \%$ hypervolemic and $17.2 \%$ hypovolemic hyponatremia. The most common causes for hyponatremia were CNS infections, CLD and acute gastroenteritis. Neurologic symptoms were more common in severe hyponatremia and seizures were attributable to hyponatremia were in $17.6 \%$ patients, all with severe hyponatremia. Deaths were more frequently seen in patients with severe hyponatremia as compared to patients with mild hyponatremia with overall mortality was $14 \%$.[8] Similarly in present study the patients with $\mathrm{Sr}$. $\mathrm{Na}^{+}<105 \mathrm{mmol} / \mathrm{L} \mathrm{had}$ (36.84\%) significant mortality compared to $>105 \mathrm{mmol} / \mathrm{L}$ ['p' <0.002196]. In current cohort of hyponatremia, total 73 $(63.47 \%)$ were males and $42(36.52 \%)$ were females with mean age of $51.63 \pm 13.73$ years with predominance of male. The diuretics (18.26\%), cardiac (13.04\%), gastrointestinal loss (7.83\%) and chronic kidney disease (CKD) (7.83\%) CVA (9.57\%), diabetes mellitus and hypertension (7.83\%) were the relatively frequent diagnosis in present study. There was no significant statistical difference between severity of hyponatremia and volume status of the patients [' $p$ '=0.7168] with predominance of euvolemia. Similarly, Mary Grace et al studied a total of 100 consecutive patients, hyponatremia (55\% male $45 \%$ female) with a mean age of $60 \pm 16$ years. The most common precipitating factor were neurological and lung conditions. Majority of the patients were asymptomatic and euvolemic at the time of detecting hyponatremia.[9] In present study the duration of hospital stay was inversely related to Sr. $\mathrm{Na}^{+}$level with negative correlation [Sr. $\mathrm{Na}^{+}<105 \mathrm{mmol} / \mathrm{L} 19.3$ $( \pm 9.5)$ days, $105-115 \mathrm{mmol} / \mathrm{L} 9.2( \pm 5.9)$ days, 115-134 mmol/L $5.7( \pm 2.4)$ days] ( $\mathrm{p}$ '=0.0014); similarly Lochan Karki et al (2016) quoted that, the hyponatremia was a common occurrence at hospital admission with an incidence of $36.11 \%$ and associated with a longer hospital stay in cured CAP patients.[10]Khalid Ali et al (2016) quoted that the patients on salt restriction, on chronic diuretic treatment, and with impaired renal function at admission were found to be highly affected with hyponatremia with increased in-hospital mortality (' $p$ '=0.008) and longer hospital stay (16.6 vs 12 days, $\mathrm{P}<0.001) .[11]$ Similarly diuretics $(18.26 \%)$, cardiac (13.04\%), gastrointestinal loss (7.83\%) and chronic kidney disease (CKD) (7.83\%) were the other aetiologies or disease condition associated with hyponatremia and severity of hyponatremia was proportional longer duration of stay and mortality in present study. Thomas Antony et al (2017) in their study of 89 patients, 50 patients had serum sodium level of less than $125 \mathrm{mEq} / \mathrm{L}$ (M:56\% and F:44\%) of them $64 \%$ of the patients were euvolaemic and $24 \%$ were hypervolaemic with SIADH was the commonest cause for hyponatremia (18\%) and Thiazide diuretics was the second $(12 \%)$ with mortality rate of $0.89 \% .{ }^{[12]}$ These findings are comparable with present study in which, the SIADH was the commonest pathophysiological process observed (37.39\%) [' $p$ ' <0.0001] for hyponatremia and diuretics intake was present in $18.26 \%$ patients with overall mortality of $(9.57 \%)$.

Hyponatremia is seen in $15-30 \%$ in Intensive care units setting. The aetiology is multifactorial. Hyponatremia may be euvolemic, hypovolemic or hypervolemic. Proper interpretation of the various laboratory tests helps to differentiate the various types of hyponatremia. A urinary sodium level below $20 \mathrm{mmol} / \mathrm{l}$ is suggestive of an extra renal cause of hypovolaemic hyponatremia. Disorientation, weakness and confusion are typically seen in chronically hyponatremia patients with sodium levels between 130-125 $\mathrm{mmol} / \mathrm{l}$. Treatment varies with the nature of onset -acute or chronic, severity and symptoms. Normal saline forms the mainstay of treatment for hypovolemic hyponatremia while $3 \% \mathrm{NaCl}$ and fluid restriction are important for euvolemic hyponatremia. Hypervolemic hyponatremia responds well to fluid restriction and diuretics.[6] There have been several recent advances in the last year with revision in the guidelines for treatment and availability of vaptans. Judicious use of vaptans may help in treatment of hyponatremia. We compared various studies with present study. (Table 7)

\begin{tabular}{|c|c|c|c|}
\hline Study & Sample Size & Symptoms & Aetiology/ Outcome \\
\hline $\begin{array}{c}\text { Nandakumar } \\
\text { et al[7] }(2013)\end{array}$ & $\mathrm{n}=60$ & $\begin{array}{c}\text { Drowsiness by vomiting, hiccoughs } \\
\text { and seizures }\end{array}$ & $\begin{array}{c}48.3 \% \text { patients had euvolemic } \\
\text { hyponatremia. SIADH was the } \\
\text { commonest cause of hyponatremia } \\
(38.3 \%)\end{array}$ \\
\hline $\begin{array}{c}\text { Mittal M et al[8] } \\
(2016)\end{array}$ & $\begin{array}{c}\text { Males:140 Females:110, } \\
53.9 \pm 16.4 \mathrm{yr}\end{array}$ & Seizures $17.6 \%$ & $\begin{array}{c}\text { Deaths were more in patients with } \\
\text { severe hyponatremia }\end{array}$ \\
\hline Mary Grace & $\mathrm{n}=100(55 \%$ male $45 \%$ & The precipitating factor for & Majority of the patients were \\
\hline
\end{tabular}




\begin{tabular}{|c|c|c|c|}
\hline et al[9] (2016) & $\begin{array}{c}\text { female) } \\
{[60+/-16]}\end{array}$ & $\begin{array}{c}\text { hyponatremia was neurological and } \\
\text { lung conditions } \\
\end{array}$ & $\begin{array}{l}\text { asymptomatic and were euvolemic at } \\
\text { the time of detection of hyponatremia }\end{array}$ \\
\hline $\begin{array}{l}\text { Lochan Karki } \\
\text { et al[10] (2016) }\end{array}$ & $\begin{array}{c}n=72 \\
F: 61 ; M: 39\end{array}$ & Incidence: $36.11 \%$ & $\begin{array}{c}\text { Mortality of } 13.7 \% \text {, mean length of } \\
\text { hospital stay: } 4.3 \text { days }\end{array}$ \\
\hline $\begin{array}{l}\text { Khalid Ali et al } \\
\text { (2016) }\end{array}$ & $n=152$ & $\begin{array}{c}\text { Salt restriction, on chronic diuretic } \\
\text { treatment }\end{array}$ & $\begin{array}{l}\text { Patients with hyponatremia had } \\
\text { increased in-hospital mortality and } \\
\text { longer hospital stay }\end{array}$ \\
\hline $\begin{array}{l}\text { Padhi R et al } \\
(2014)^{[13]}\end{array}$ & $\begin{array}{l}\text { Mean age was } 60.4 \pm 17.2 \text {. } \\
\text { Frequency: } 34.3 \%, 58.96 \%\end{array}$ & $\begin{array}{c}\text { SIADH criteria was met in } 36.25 \% \text {, } \\
\text { pneumonia being the leading cause } \\
\text { of SIADH / euvolemic }\end{array}$ & $\begin{array}{c}\text { The hyponatremia group a longer stay, } \\
\text { longer ventilator days and had more } \\
\text { mortality }\end{array}$ \\
\hline $\begin{array}{c}\text { Babaliche P } \\
\text { et al[14] } \\
(2017) \\
\end{array}$ & $\begin{array}{c}\mathrm{n}=100 \\
\text { Prospective cross-sectional } \\
\text { study } \\
\end{array}$ & $\begin{array}{c}\text { S/S: Vomiting confusion. } \\
\text { SIADH\& euvolemic renal } \\
\text { dysfunction\& Drug }\end{array}$ & $\begin{array}{l}\text { Hyponatremia infectious cause should } \\
\text { be meticulously screened for } \\
\text { tuberculosis }\end{array}$ \\
\hline $\begin{array}{l}\text { Patil S et al[15] } \\
\quad(2016)\end{array}$ & $\begin{array}{c}\text { Cross-sectional } \\
\mathrm{n}=100, \text { Hyponatremia: } 100 \\
\text { non-hyponatremia } 50\end{array}$ & $\begin{array}{c}\text { 66\% patients had seizures, reduced } \\
\text { consciousness level, confusion, } \\
\text { unsteadiness, and falls }\end{array}$ & $\begin{array}{l}\text { Most aetiology was severe sepsis, renal } \\
\text { failure, liver cirrhosis, trauma, } \\
\text { hypothyroidism, hypocortisolism. } \\
\text { Longer duration stay in ICU with higher } \\
\text { mortality rate }\end{array}$ \\
\hline $\begin{array}{c}\text { Paniker GI } \\
\text { et al[16] }(2014)\end{array}$ & $\mathrm{n}=100$ & Confusion & $\begin{array}{c}\text { Commonest aetiology was SIADH and } \\
\text { pneumonia. Mortality: } 4 \%\end{array}$ \\
\hline $\begin{array}{l}\text { Gopinath H } \\
\text { et al[17] (2016) }\end{array}$ & $\mathrm{n}=50$ & $\begin{array}{l}\text { Hypertension and } \\
\text { diuretics and excessive renal loss }\end{array}$ & $\begin{array}{l}\text { Diabetes mellitus and dyslipidaemia } \\
\text { were important co-morbidities of } \\
\text { hyponatremia }\end{array}$ \\
\hline $\begin{array}{l}\text { Parijat } P \text { et al }[18] \\
\qquad(2015)\end{array}$ & & $\begin{array}{l}\text { Nausea, vomiting and drowsiness are } \\
\text { the commonest symptoms }\end{array}$ & $\begin{array}{l}\text { Increasing age, hypertension, diabetes } \\
\text { mellitus and use of drugs (diuretics). } \\
\text { Hyponatremia acts as a poor prognostic } \\
\text { marker }\end{array}$ \\
\hline Present study & $\begin{array}{c}\mathrm{n}=115 \text {; Males: } 73(63.47 \%), \\
\text { Females: } 42(36.52 \%)\end{array}$ & $\begin{array}{l}\text { Confusion, seizures and coma were } \\
\text { associated with moderate to } \\
\text { profound hyponatremia }\end{array}$ & $\begin{array}{l}\text { Mild hyponatremia was common and } \\
\text { the SIADH was the commonest } \\
\text { aetiology. The duration of hospital stay } \\
\text { was inversely related to } \mathrm{Na}^{+} \text {levels. } \\
\text { Overall mortality of } 9.57 \% \text { correlated } \\
\text { with severity of hyponatremia }\end{array}$ \\
\hline
\end{tabular}

Rao MY et al studied 100 patients with hyponatremia with CNS manifestations with mortality rate of $9.09 \%$ with SIADH was the aetiology with hypertension and DM was the frequent co-morbidity these findings are comparable with present study.[19] In the evaluation of the hyponatremia patient, history taking should focus on identifying the potential cause, duration and symptomatology. Clinical examination should include assessment of volume status. Acute hyponatremia of less than $48 \mathrm{~h}$ duration requires prompt correction.[20]

\section{CONCLUSION}

Hyponatremia is a frequent electrolyte eccentricity found in the present study. All the symptomatic cases had moderate to severe hyponatremia. Cerebrovascular accident was the frequent diagnosis of patients with hyponatremia and diabetes mellitus and the hypertension was the common comorbidity in the present study. The most common aetiology was euvolemia with SIADH. Hyponatremia was found to be related to multiple aetiological factors in a large number of patients. There was significant alliance between serum sodium levels and symptoms and outcome of the patients. Central nervous system symptoms were often seen in severe hyponatremia. The mortality and prolonged duration of stay and mortality was often correlated with severity of hyponatremia. A well-structured approach to the diagnosis of hyponatremia with the application of simple diagnostic algorithms, using history, clinical examination and laboratory findings to establish protocol of hyponatremia can significantly improve the outcome of hyponatremia.

\section{REFERENCES}

[1] Spasovski G, Vanholder R, Allolio B, et al. Clinical practice guideline on diagnosis and treatment of hyponatraemia. Nephrol Dial Transplant 2014;29(Suppl 2):i1-i39.

[2] Corona G, Giuliani C, Parenti G, et al. Moderate hyponatremia is associated with increased risk of mortality: evidence from a meta-analysis. PLoS One 2013;8(12):e80451.

[3] Kasper D, Fauci A, Hauser S, et al. Harrison's Principles of internal medicine. $19^{\text {th }}$ edn. New York, NY: McGrawHill 2015: p. 169-70, 277-8.

[4] Scott MG, LeGrys VA, Klutts JS. Electrolytes and blood gases. In: clinical chemistry and molecular diagnostics. $3^{\text {rd }}$ edn. Philadelphia: WB Saunders 2007: p. 468-83.

[5] Nagler EV, Vanmassenhove J, van der Veer SN, et al. Diagnosis and treatment of hyponatremia: a systematic review of clinical practice guidelines and consensus statements. BMC Medicine 2014;12:231.

[6] Sahay M, Sahay R. Hyponatremia: a practical approach. Indian J Endocrinol Metab 2014;18(6):760-71.

[7] Nandakumar, Gane B, Hiremath PB. Clinicoaetiological profile of hyponatremia in adults. Int J Biol Med Res 2013;4(1):2802-6.

[8] Mittal M, Deepshikha, Khurana H. Profile of hyponatremia in a tertiary care centre in North India. Int J Adv Med 2016;3(4):1011-5. 
[9] Grace MNC, Jacob KJ, Rajesh KR, et al. A prospective study on the clinical profile and outcome of patients with hyponatremia in a tertiary care centre in Kerala, South India. Public health Rev: Int J Public Health Res 2016;3(2):70-4.

[10] Karki L, Thapa B, Sah MK. Hyponatremia in patients with community acquired pneumonia. J Nepal Med Assoc 2016;54(202):67-71.

[11] Ali K, Workicho A, Gudina EK. Hyponatremia in patients hospitalized with heart failure: a condition often overlooked in low-income settings. International Journal of General Medicine 2016;9:267-73.

[12] Antony T, Iqbal N, Mookkappan S, et al. Clinical profile and etiology of severe hyponatraemia in a tertiary care hospital of South India. J Evid Based Med Healthc 2017;4(21):1172-5.

[13] Padhi R, Panda BN, Jagati S, et al. Hyponatremia in critically ill patients. Indian J Crit Care Med 2014;18(2):83-7.

[14] Babaliche P, Madnani S, Kamat S. Clinical profile of patients admitted with hyponatremia in the medical intensive care unit. Indian J Crit Care Med 2017;21(12):819-24.
[15] Patil S, Mukherji A, Shetty A. Incidence of hyponatremia in critically ill patients in intensive care unit: observational study. Int J Dent Med Spec 2016;3(1):12-5.

[16] Paniker GI, Joseph S. A prospective study on clinical profile of hyponatremia in ICU hospitalized patients. International Journal of Biomedical and Advance Research 2014;5(6):297-303.

[17] Gopinath H, Duraickannu T, Mohan R, et al. An open model cross sectional observational study of hyponatremic patients in a tertiary care hospital. Int J Res Med Sci 2016;4(3):713-7.

[18] Baji PP, Borkar SS. Clinico-etiological profile and outcome of hyponatremia in hospitalised adult patients. Int J Sci Rep 2015;1(7):293-8.

[19] Rao MY, Sudhir U, Kumar AT, et al. Hospital-based descriptive study of symptomatic hyponatremia in elderly patients. J Assoc Physicians India 2010;58:6679.

[20] Biswas M, Davies JS. Hyponatraemia in clinical practice. Postgrad Med J 2007;83(980):373-8. 